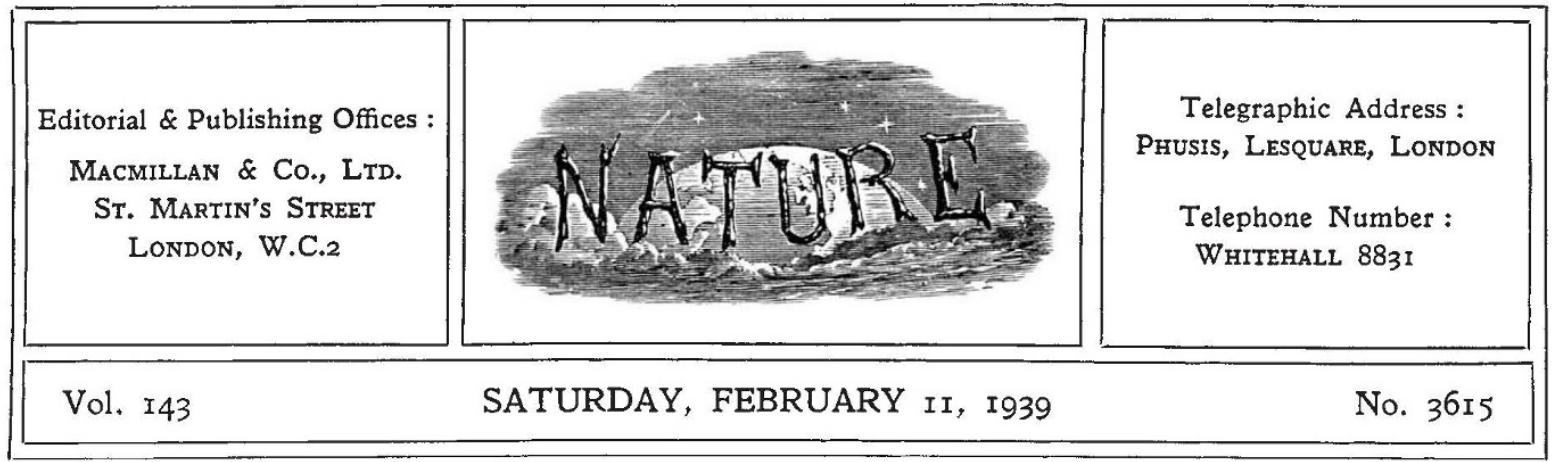

\title{
Agricultural Research and Education
}

$\mathrm{T}$ HERE can be few to-day who would deny that scientific research lies at the base of material progress. Ninety years ago or more, the Prince Consort recognized the fact; but it was not until the middle of the Great War that the Government in Great Britain first embarked upon a comprehensive scheme of State assistance for industrial and scientific research. Agriculture was a little more fortunate, because, thanks to the perspicacity of Mr. Lloyd George, a Development Fund was established in 1910-11 which, among other objects, was designed to aid and develop agriculture and rural industries. Since that time, an increasing amount of money has been given to promote and maintain agricultural research, and in the year 1938 the State spent at least $£ 700,000$ on this object in Great Britain. This sum represents about 90 per cent of the total expenditure on agricultural research and advisory services, to which farmers themselves contribute very little, and is distributed among some fifty institutions, of which twentyeight are devoted solely or primarily to research.

The chief recipients of grants are agricultural colleges and university departments of agriculture, which also have educational functions; State institutions, like the Veterinary Laboratory at Weybridge, Surrey; and private institutions, like Rothamsted, the Rowett Institute, and the Royal Veterinary College, London. There are 673 research workers at the chief institutions and the total number in Great Britain is rather less than one thousand. Propagation of the results of research, and general advisory work, are delegated to seventeen principal advisory officers located in sixteen provincial advisory centres which are usually university departments or agricultural colleges, and lower down the scale are advisory officers and agricultural organizers appointed by agricultural education committees of county councils. The councils make small grants for research to university departments, agricultural colleges and research institutes. Research is also conducted by private interests like Imperial Chemical Industries Ltd. at Jealott's Hill, and the Wellcome Physiological Laboratories at Beckenham, Kent. Lastly, there are nine Imperial bureaux and two Imperial institutes which collect and collate information and abstract the scientific literature for research workers throughout the Empire.

The above and many more interesting and relevant facts are set out in an admirable report published by $\mathrm{PEP}^{*}$, which records the findings of a special committee it appointed to examine the adequacy of the provision made for agricultural research in Great Britain, how it is administered, and to what extent the measures taken to get farmers to utilize the results have been successful. The report sees much to commend in the provisions made for agricultural research, but it is also critical, and in the interests of progress, our remarks will be confined in the main to two objects of criticism : the cumbersome machinery of administration and finance, and the failure to 'put over' the results of research to working farmers.

Responsibility for the administration and finance of agricultural research in Great Britain is divided among numerous authorities of the central Government: the Agricultural Research Council, the Development Commission, the Ministry of Agriculture for England and Wales, the Department

* Report on Agricultural Research in Great Britain : a Survey of its Scope, Administrative Structure and Finance, and of the Methods of making its Results known to Farmers, with Proposals for Future Development. Pp. vi +146 . (London: P E P 1938.) 8s. 6d. net. 
of Agriculture for Scotland, the Dominions Office (for the Imperial institutes and bureaux), the Privy Council, and the Treasury. This multiplicity of authorities has many drawbacks, and PEP advises that the Development Commission, which has already lost some of its initial functions, should be abolished as a piece of "superfluous stage property". Many will think that the pruning process might be extended, but excessive devotion to old forms and traditions, and a propensity to compromise, seem to be a characteristic of the governmental mind in Great Britain. Government departments are, of course, always fair game for carping critics, but more than one Government inquiry in recent years has recommended the application of the axe.

The organization of agricultural research institutes is criticized by PE P in so far as it is based too largely upon departmental science: more husbandry institutes are wanted, each of which would specialize in a particular crop or product rather than upon a particular science. The low salaries paid to research workers are deprecated, and the creation of a central agricultural research fund, with larger contributions from the industry, is advocated.

The most serious criticism against the existing order is failure to get the results of research translated into farming practice, a failure which, in our opinion, cannot be ascribed entirely to the agricultural education authorities or to the systems under which they work. Agricultural education in England is under three administrations: the Ministry of Agriculture, the Board of Education, and the county councils. From the agricultural colleges and university departments some 2,000 students pass out every year, but surprisingly few of them take up farming on their own account, either because they lack the necessary capital, or because no managerial posts are open to them. most of them take up teaching, or go into administrative service, or join the larger commercial firms.

Agricultural education for the rank and file is administered by the county councils, each of which commands the services of a county agricultural organizer, district organizers, and special instructors. The staffing varies greatly between county and county, and in general the number of instructors appears to be inadequate. Of the 22,000 students who come under the county councils, about half receive their instruction in evening classes only. In addition to itinerant teaching, the county staffs undertake demonstrations and advisory work. Education is also provided, mostly during the winter months, by the residential farm institutes, in which the teaching is essentially practical. Technical instruction is given in senior schools and in instruction classes financed by the county education committees and the Board of Education. The Young Farmers' Clubs also have educational functions ; and lastly, the farming community can gather knowledge and advice from broadcast 'talks', from departmental publications designed to popularize recent advances in technique, and from the agricultural press.

With this medley of administrative organs and public and private agencies, it is small wonder that results have proved disappointing. Agricultural education, like many other institutions of the civilized world, has become far too complex, and only the surgeon's knife followed by Occam's razor can bring us back to simplicity and efficieney. PEP proposes that the county advisory services be transferred to the provincial advisory centres, but other critics would have all the agricultural educational functions of the county councils so transferred. Many would like to see a great extension of the farm institutes, which have accommodation for only a fraction of the youth destined for the land, and their utilization for short courses of instruction for skilled specialized workers.

But perhaps the greatest handicap to the spread of new scientific knowledge is the character of the farmers themselves. Farmers of the old typethey are still in a large majority-who have inherited the prejudices as well as the consummate skill of their forbears usually shy at the sight of the scientific adviser, a reaction that may be partly due to unhappy experience of projects they were induced to adopt by well-meaning but unpractical enthusiasts. On the other hand, there is arising a new generation of farmers, more appreciative and keen, who, if less skilled than their fathers in the old methods applicable to bygone conditions, are open to new ideas and thoroughly progressive in outlook. The day of the old practical farmer is passing - of the man who could himself efficiently perform all the manual tasks of the farm. He was, in essence, a farm labourer with capital. Unless we are to perpetuate peasant farming, it is as unreasonable to expect the modern, and especially the future, farmer to be an expert in the everyday jobs of the farm, as it 
is now to insist on the manager of an engineering works being able to undertake all the tasks in his workshop.

As the $\mathrm{P} E \mathrm{P}$ report indicates, the main hope for the future lies in reformed education in the primary and secondary schools, rather than in the higher seats of learning. Agricultural research is far ahead of agricultural education. Vocational instruction is not wanted in primary schools. The claims of English, arithmetic, geography and an outline of world history must be recognized, but more scope is required for what is termed 'general science', the teaching of broad outlines largely through applications. The pupil who is destined for the land should, we suggest, leave school at fourteen to fifteen years of age, and serve an apprenticeship lasting one to two years on an up-to-date farm, where he would be encouraged to relate his school science to the facts ' of farming. $\mathrm{He}$ should then return to school, continue his general education, and pursue a more specialized course of instruction in those sciences that bear directly upon agriculture. So trained, it is difficult to conceive of any youth, other than a 'throw-back', entering agriculture without an informed mind and a progressive outlook. Besides instilling knowledge and training the mind to think, education for agriculture, or for any other pursuit, can only be worthy of the name if it inculcates such essential social virtues as willingness to co-operate and consideration for others.

\section{State Control of Private Forests}

Forestry and State Control

By Prof. R. S. Troup. Pp. vii +88 . (Oxford : Clarendon Press; London: Oxford University Press, 1938.) 3s. 6d. net.

$\mathrm{T}$ $\mathrm{HE}$ condition of private woodlands in Britain has been the subject of increasing concern ever since the British people. began to realize that their former complacent reliance on continuous supplies of timber from abroad is not so well founded as they supposed. The main part of the task of building up a reserve of softwood timber in the country for use in times of emergency has been entrusted to the Forestry Commissioners, but in assigning them their share in this work, it was assumed that through their encouragement and example private woodlands, both hardwood and softwood, would be restored to their pre-War area and their productivity improved. Unfortunately, it has become evident that this assumption was not justified and, as questions of national defence, economic self-sufficiency and political interferences with the flow of trade and commerce seem to be increasing rather than diminishing in im. portance, it is not surprising if the advisability of taking more intensive measures in regard to private forestry has come to the fore.

The whole tradition of Britain has been against State interference with private productive enterprise, and State action as regards private forestry up to the present has been confined to attempts to induce the private owner to practise more and better forestry by propaganda, provision of technical education and advice, taxation concessions, planting subsidies and assisted marketing. In many countries, however, the action of the State goes far beyond such measures as these, and may extend to legal restrictions on felling, and insistence on the regeneration of felled areas, employment of certain sylvicultural systems, etc. The degree of control exercised may extend from mere inspection of the forests, to see that the law is not evaded, to the actual management of private woodlands by State forest officers.

In this book, Prof. R. S. Troup gives an account of the methods of control over private forests practised in the chief European countries, and discusses, in the light of knowledge gained by personal visits and inquiries, the actual working of these measures and the attitude of private owners to control by the State. The first half of the work is devoted to a general account of the nature and ownership of forests and a discussion of the question of whether, and in what circumstances, State control of private forests is justified.

After a review of the position of British forestry, the author expresses the opinion that, besides the incidence of death duties and the economic forces acting against forestry in Britain, the main cause of the poor productivity of private woodlands is the absence of adequate technical knowledge on the part of those responsible for their management. The remedy for inefficient management is the employment of properly trained forest managers, but most woodland estates are too small to justify 